\title{
Necessity of Epigenetic Epidemiology Studies on the Carcinogenesis of Lung Cancer in Never Smokers
}

\author{
Jong-Myon Bae \\ Department of Preventive Medicine, Jeju National University School of Medicine, Jeju, Korea
}

Based on epidemiological and genomic characteristics, lung cancer in never smokers (LCNS) is a different disease from lung cancer in smokers. Based on current research, the main risk factor for LCNS may be air pollution. A recent case-control study in Koreans reported that nitrogen dioxide $\left(\mathrm{NO}_{2}\right)$ may be a risk factor for LCNS. Additionally, a cohort study showed that exposure to $\mathrm{NO}_{2}$ was associated with significant hypomethylation. Thus, epigenetic epidemiology studies are needed in the near future to evaluate the carcinogenesis of LCNS according to chronic exposure to air pollution and/or viral infections.

Key words: Air pollution, Gene-environment interaction, Epigenetics, Epidemiology

Cigarette smoking is linked to $80 \%$ of lung cancer cases among males and $45 \%$ among females [1]. Nonetheless, this implies that lung cancer occurs among never smokers, and in fact, lung cancer in never smokers (LCNS) accounts for $25 \%$ of all cases and $55 \%$ of female cases. Some experts have claimed that LCNS should be considered a different disease from lung cancer in smokers [1] on the grounds that unlike the latter, it is found more frequently among female patients, is histologically a type of adenocarcinoma, often affects younger individuals, shows a good prognosis, and is responsive to epidermal growth factor receptor-tyrosine kinase inhibitors [2].

Couraud et al. [3] summarized the risk factors of lung cancer other than smoking, as shown in Table 1. Among these factors, human papillomavirus (HPV) infection and hormonal factors

Received: March 23, 2018 Accepted: July 8, 2018

Corresponding author: Jong-Myon Bae, MD, PhD

Department of Preventive Medicine, Jeju National University School of Medicine, 102 Jejudaehak-ro, Jeju 63243, Korea

E-mail: jmbae@jejunu.ac.kr

This is an Open Access article distributed under the terms of the Creative Commons Attribution Non-Commercial License (http://creativecommons.org/licenses/by$\mathrm{nc} / 4.0 /$ ) which permits unrestricted non-commercial use, distribution, and reproduction in any medium, provided the original work is properly cited. are modifiable [4]. Moreover, the top 5 factors in Table 1-exposure to environmental tobacco smoke, exposure to radon, air pollutants, household fumes, and occupational exposure to carcinogens-all fall under the category of air pollution, which has been defined as "contamination of the atmosphere by gaseous, liquid, or particulate waste (or its by-products) that can cause harm or discomfort to humans or other living organisms, and/or cause damage to the environment" [5]. This indicates that air pollution is the major risk factor for LCNS [3].

A case-control study conducted in Korea, 2017 [6] conclud-

Table 1. Risk factors of lung cancer other than smoking

Exposure to environmental tobacco smoke
Environmental exposure to radon
Air pollutants
Household fumes
Occupational exposure to carcinogens
Infectious factors
Other medical history
Hormonal factors (women)
Dietary factors, alcohol, and diabetes
Socioeconomic status

Adapted from Couraud et al. Eur J Cancer 2012;48(9):1299-1311 [3]. 
ed that nitrogen dioxide $\left(\mathrm{NO}_{2}\right)$ increased the risk of LCNS (odds ratio, 1.17; 95\% confidence interval, 1.01 to 1.34). Exposure to $\mathrm{NO}_{2}$ may cause hypomethylation [7]. Hypomethylation of DNA is a kind of epigenetic alteration that affects gene expression and leads to the development of cancer [8]. Particulate matter (PM) and radon are other factors known to evoke hypomethylation, which can be better understood through epigenetic epidemiological studies [9]. Epigenetic studies will be also necessary to understand the carcinogenesis of LCNS caused by "infectious factors," as noted in Table 1, as viral miRNA from the Epstein-Barr virus or HPV may bring about epigenetic mutations [8].

An increasing number of epigenetic studies have been conducted in recent years on surfactant proteins to explore the link between air pollution and lung cancer [5,9]. However, it is difficult to find any epigenetic study on risk of LCNS by air pollution. Given the high level of social concern regarding PM, more epigenetic case-control studies on air pollution and cardiopulmonary diseases, including LCNS, are necessary. The results of such studies may enable the evaluation of individual susceptibility to lung cancer, early diagnosis, and treatment [10].

\section{CONFLICT OF INTEREST}

The author has no conflicts of interest associated with the material presented in this paper.

\section{SUPPLEMENTAL MATERIALS}

Supplementary Material: Korean version is available at https://www.jpmph.org/.

\section{ORCID}

Jong-Myon Bae https://orcid.org/0000-0003-3080-7852

\section{REFERENCES}

1. Sun S, Schiller JH, Gazdar AF. Lung cancer in never smokersa different disease. Nat Rev Cancer 2007;7(10):778-790.

2. Okazaki I, Ishikawa S, Ando W, Sohara Y. Lung adenocarcinoma in never smokers: problems of primary prevention from aspects of susceptible genes and carcinogens. Anticancer Res 2016;36(12):6207-6224.

3. Couraud S, Zalcman G, Milleron B, Morin F, Souquet PJ. Lung cancer in never smokers-a review. Eur J Cancer 2012;48(9): 1299-1311.

4. Bae JM. Modifiable risk factors of lung cancer in "never-smoker" women. Epidemiol Health 2015;37:e2015047.

5. Silveyra P, Floros J. Air pollution and epigenetics: effects on SP-A and innate host defence in the lung. Swiss Med Wkly 2012;142:w13579.

6. Lamichhane DK, Kim HC, Choi CM, Shin MH, Shim YM, Leem $\mathrm{JH}$, et al. Lung cancer risk and residential exposure to air pollution: a Korean population-based case-control study. Yonsei Med J 2017;58(6):1111-1118.

7. Plusquin $M$, Guida F, Polidoro S, Vermeulen R, Raaschou-Nielsen O, Campanella G, et al. DNA methylation and exposure to ambient air pollution in two prospective cohorts. Environ Int 2017; 108:127-136.

8. Lin VW, Baccarelli AA, Burris HH. Epigenetics-a potential mediator between air pollution and preterm birth. Environ Epigenet 2016;2(1):dvv008.

9. Vaid M, Floros J. Surfactant protein DNA methylation: a new entrant in the field of lung cancer diagnostics? (Review). Oncol Rep 2009;21(1):3-11.

10. Bae JM. Interpretation of the hygiene and microflora hypothesis for allergic diseases through epigenetic epidemiology. Epidemiol Health 2018;40:e2018006. 